\title{
ASYMPTOMATIC MISSING INTRAUTERINE CONTRACEPTIVE DEVICE FOUND INCIDENTALLY DURING VAGINAL HYSTERECTOMY
}

Reena Sharma1, Usha Kumari Chaudhary², Ajay Sharma ${ }^{3}$, Arvind Kumar ${ }^{4}$, Meghna Thusoo ${ }^{5}$

\section{HOW TO CITE THIS ARTICLE:}

Reena Sharma, Usha Kumari Chaudhary, Ajay Sharma, Arvind Kumar, Meghna Thusoo. "Asymptomatic Missing Intrauterine Contraceptive Device Found Incidentally During Vaginal Hysterectomy". Journal of Evolution of Medical and Dental Sciences 2015; Vol. 4, Issue 52, June 29; Page: 9137-9139,

DOI: $10.14260 /$ jemds/2015/1327

ABSTRACT: Incidence of missing IUCD iy is $0.5 \%-2 \%$. Usually the cause is either expulsion or perforation of uterus. Sometimes the perforated IUCD remains asymptomatic for years together and found incidentally later on. We hereby presenting a case of 55 yrs female presenting with prolapsed uterus, planned for vaginal hysterectomy. During vaginal hysterectomy asymptomatic missing IUCD was detected which was found on the anterior surface of body of uterus with omentum adherent to it. KEYWORDS: Missing Cu T, IUCD, Omentum, Perforation.

MESHTERMS: Misplaced IUCD, Asymptomatic missing IUCD.

INTRODUCTION: Intrauterine contraceptive device (IUCD) is an acceptable contraceptive method worldwide; percentage of women using IUCD is between $5-40 \%{ }^{1}$

Uterine perforation is a serious and rare complication, incidence of which is 1 in 350 to 1 in $2500.2,3$

CASE REPORT: We report here an asymptomatic patient with missing $\mathrm{Cu}-\mathrm{T}$. Patient remained asymptomatic for 25 years and $\mathrm{Cu}$ - $\mathrm{T}$ found embedded on the anterior surface of the body of uterus adherent with omentum, while doing vaginal hysterectomy.

Mrs. X, 55 years old, $\mathrm{P}_{4} \mathrm{~L}_{4}$ presented in the Gynecology outpatient department with complaint of something coming out of introitus since 20 years. There was no other complaints. Patient had menopause 10 years back. In obstetrics history, patient married for 35 years, her last child birth was 25 years backandhistory of $\mathrm{Cu}$-T insertion 3 months after the last childbirth. On one $\mathrm{Cu}$ - $\mathrm{T}$ follow up visit, she was told after examination that $\mathrm{Cu}$ - $\mathrm{T}$ threads are not visible and she might have expelled it. She was advised to undergo tubectomy. Tubectomy was done 7 years after the last childbirth.

General physical examination was normal. On local examination cervix lying $2 \mathrm{~cm}$ outside the introitus, cervicitis+, no decubitus ulcer, cystocoele+, rectocoele+, no enterocoele, on reposition per vaginum examination: uterus retroverted, multiparous size, firm, mobile, right adenexa thickened. The complete blood counts, renal function tests, liver function tests, serum electrolytes, chest X-ray, echocardiogram were normal. Patient was planned and prepared for vaginal hysterectomy with perineal floor repair under combined spinal epidural anaesthesia.

During intra-operative period after opening pouch of douglous and uterovesical pouch, there was difficulty in delivering out the uterus as there was the adhesions of omentum with anterior surface of body of the uterus.On further pullinga $\mathrm{Cu}$-T adherent to the omentum on anterior surface of the body of uterus was seen. Adhesions of the omentum broken and $\mathrm{Cu}$-T removed enmasse with uterus and cervix. Rest of the procedure completed and uterus with cervix and adherent $\mathrm{Cu}$ - $\mathrm{T}$ sent for histopathological examination. 
DISCUSSION: The prevalence of missing intrauterine contraceptive device among users is 0.5 to $2 \%{ }^{4}$ Missing IUCDis when $\mathrm{Cu}$-T threads are not visible in vagina, as a result of expulsion or perforation of uterus (frank or occult), but occasionally there is migration of $\mathrm{Cu}-\mathrm{T}$ in peritoneal cavity. ${ }^{5}$

Migration of $\mathrm{Cu}-\mathrm{T}$ is considered due to procedure itself or a chronic inflammatory reaction withgradual erosion through the uterine wall, incidence of which depend on the timing of insertion, parity, history of previous abortions, type of IUCD, experience of operator anduterine size, position and consistency of the uterus. ${ }^{2}$

In the literature there have been reported cases of intraperitoneal IUCDs presenting with abdominal pain, pregnancies, uterine perforation with associated intraabdominal abscesses, vesical stones, appendicitis and in fact, ureteric obstruction leading to nephrectomy. ${ }^{6-8}$

Detection of missing IUCD could be done by ultrasonography, pelvic- abdominal radiography, laproscopy and hysteroscopy.3,5,9 Ultrasonography is unrealiable if $\mathrm{Cu}-\mathrm{T}$ device is surrounded by omentum or loops of bowl.10

Commonly seen symptoms by displaced $\mathrm{Cu}$-T include abdominal pain and menorrhagia but asymptomatic patients with silent perforations have been reported.

Management of extrauterine displaced $\mathrm{Cu}$ - $\mathrm{T}$ is controversial, but all $\mathrm{Cu}-\mathrm{T}$ devices should be removed electively as soon as detected to avoid complications like damage to adjacent organs, adhesions, bowel obstruction and medico legal problems.

CONCLUSION: In our country, fertility control is the need of the hour. Our aim should be to bring down the failure and complication rates of these methods for increasing the acceptance of contaceptive methods. $\mathrm{Cu}-\mathrm{T}$ is a safe and cheap method of contraception so we should take all the precautions to avoid such complications. The woman should be educated to check for the threads periodically and report immediately in case of non localisation. If a woman doesnot observe the expulsion of $\mathrm{Cu}$ - $\mathrm{T}$ device and there is missing thread on follow up, then it should be considered as extrauterine translocation until contrary is proved.

\section{REFERENCES:}

1. Centre for Disease Control. Intrauterine Contraceptive Devices - In Family Planning Methods and Practices in Africa. 3rd edition.CDC Atlanta, Georgia 1983.

2. SF Heartwell, S Schhlesselman. Risk of uterine perforation among users of intrauterine devices. ObstetGynecol 1983; 61: 31 - 6.

3. S Mittal, I Gupta, P Lata, U Mahajan, AN Gupta. Management of translocated and incarcerated intrauterine devices. Aust NZ J Obstet Gynecol 1986; 26: 232 - 4.

4. Lawal SO, Giwa-Osagie OF, Ogedengbe OK, Usifor CA. A review of IUCDrelated problems in Lagos University Teaching Hospital (LUTH). West Afr J Med. 1993; 12: 144-7.

5. Rahman GA.Yusuf IF.Asymptomatic missing intrauterine contraceptive device found incidentally at laparotomy. J Pak Med Assoc.2009 Apr; 59 (4): 255-6.

6. Rafique M. Vesical calculus: a complication of intravesical migration of intrauterine contraceptive device. Int Urogynecol J Pelvic Floor Dysfunct 2002; 13: 380-2.

7. Serra I. Appendicitis caused by an intrauterine contraceptive device Br J Surg 1986; 73: 927-8.

8. Timonen H, Kurppa K IUD perforation leading to obstructive nephropathy necessitating nephrectomy: a rare complication. Adv Contracep 1987; 3: 71-5. 


\section{CASE REPORT}

9. Jillani K. Khero RB. Maqsood S. Diagnosis and management of misplaced intrauterine contraceptive device (IUCD). Pak J Surg2010; 26 (2): 151-4.

10. Zakin D, Stern WZ, Rosenblatt R. Complete and partial uterine perforation and embedding following insertion of intrauterine devices. II. Diagnostic methods, prevention, and management. Obstet Gynecol Surv 1987; 36: 401-17.

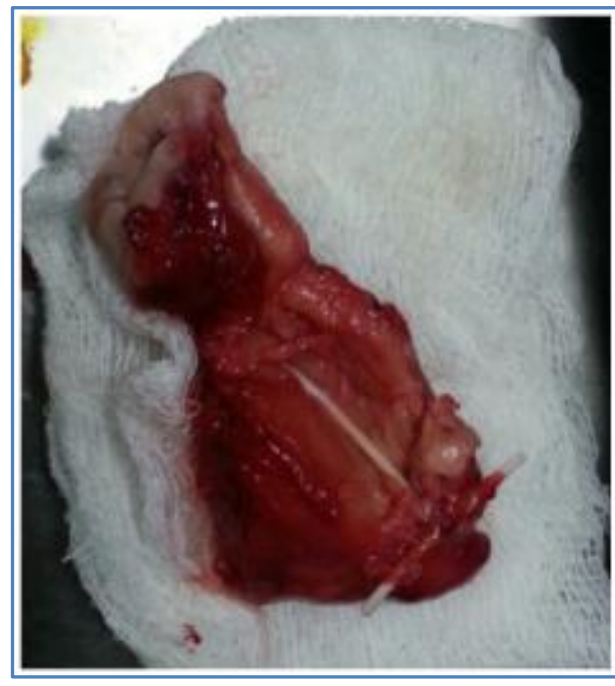

Fig. 1: Showing Cu-T embedded on body of uterus adherent to omentum

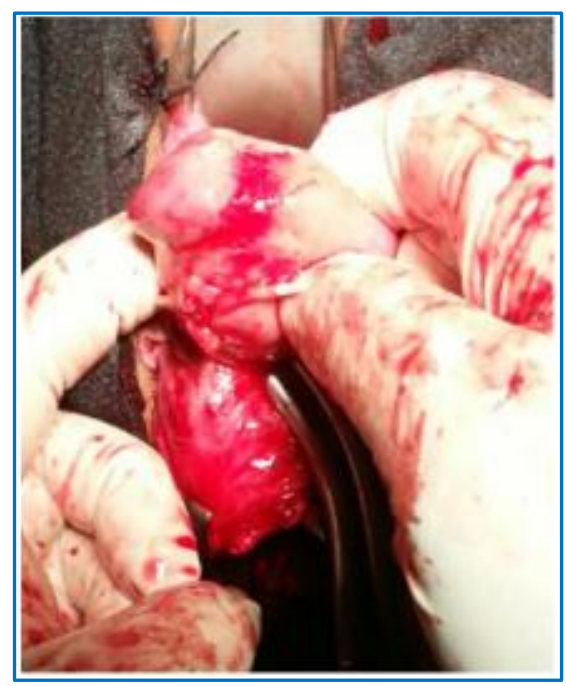

Fig. 2: Showing Cu-T embedded in the body of uterus

\section{AUTHORS:}

1. Reena Sharma

2. Usha Kumari Chaudhary

3. Ajay Sharma

4. Arvind Kumar

5. Meghna Thusoo

\section{PARTICULARS OF CONTRIBUTORS:}

1. Senior Resident, Department of Obstetrics \& Gynaecology, Dr. RPGMC, Tanda, Kangra, H. P.

2. Senior Resident, Department of Anaesthesia, Dr. RPGMC, Tanda, Kangra, H. P.

3. Senior Resident, Department of Cardiology, Dr. RPGMC, Tanda, Kangra, H. P.

\section{FINANCIAL OR OTHER} COMPETING INTERESTS: None
4. Junior Resident, Department of Pharmacology, Dr. RPGMC, Tanda, Kangra, H. P.

5. Senior Resident, Department of Obstetrics \& Gynaecology, Dr. RPGMC, Tanda, Kangra, H. P.

\section{NAME ADDRESS EMAIL ID OF THE CORRESPONDING AUTHOR:}

Dr. Usha Kumari Chaudhary,

Senior Resident,

Department of Anaesthesia,

Dr. RPGMC, Tanda,

Kangra, H. P, India.

E-mail: chaudhary.ushaarvind@gmail.com

Date of Submission: 10/06/2015.

Date of Peer Review: 11/06/2015.

Date of Acceptance: 24/06/2015.

Date of Publishing: 29/06/2015. 